\title{
KESESUAIAN ANTARA PENILAIAN BELAJAR OLEH GURU PRODUKTIF DENGAN STANDAR PENILAIAN PENDIDIKAN PADA MATA PELAJARAN TEKNOLOGI DASAR OTOMOTIF
}

\author{
Pipit A. Fatah ${ }^{1}$, Inu H. Kusumah², Mumu Komaro ${ }^{3}$ \\ Universitas Pendidikan Indonesia \\ Jl. Dr. Setiabudhi No. 229 Bandung 40154 \\ apipitaf@gmail.com
}

\begin{abstract}
ABSTRAK
Penelitian ini bertujuan untuk mengetahui kesesuaian antara penilaian belajar oleh guru produktif SMK dengan Standar Penilaian Pendidikan pada mata pelajaran Teknologi Dasar Otomotif di SMKN 6 Bandung. Data diperoleh dengan menyebarkan angket kepada responden yaitu para siswa kelas X Teknik Kendaraan Ringan di SMKN 6 Bandung, serta dengan meninjau dokumen-dokumen pendukung penilaian belajar. Populasi dalam penelitian ini berjumlah 210 siswa dan sampel dalam penelitian ini berjumlah 68 siswa. Teknik pengambilan sampel yang digunakan yaitu simple random sampling. Analisis data yang digunakan adalah analisis deskriptif persentase dengan hasil kesesuaian $87,1 \%$ pada tahap persiapan penilaian belajar, $77 \%$ pada tahap pelaksanaan penilaian belajar, $43,22 \%$ pada tahap tindak lanjut penilaian belajar, serta $83,3 \%$ pada tahap pelaporan penilaian belajar. Kesimpulan penelitian menunjukan bahwa pelaksanaan penilaian belajar di SMKN 6 Bandung khususnya pada mata pelajaran Teknologi Dasar Otomotif, lebih dari setengahnya telah sesuai dengan Standar Penilaian Pendidikan.
\end{abstract}

Kata kunci: penilaian belajar, guru produktif, standar penilaian, otomotif

\section{PENDAHULUAN}

Fungsi dan maksud dari pelaksanaan pendidikan yaitu untuk memperbaiki kualitas diri peserta didik. Pendidikan yang berkualitas dan bermutu akan tercapai apabila terpenuhinya standar-standar yang ditetapkan oleh pemerintah. Standar yang dimaksud yaitu Standar Nasional Pendidikan. Standar Nasional Pendidikan terdiri atas 8 (delapan) standar, salah satunya adalah Standar Penilaian Pendidikan. Standar Penilaian Pendidikan adalah kriteria mengenai mekanisme, prosedur, dan instrumen penilaian hasil belajar peserta didik (Arifin, 2012). Penilaian ini dilakukan oleh tenaga pendidik dan Satuan Pendidikan dan Pemerintah.

Ada beberapa prosedur dan standar yang ditetapkan oleh pemerintah dalam hal Penilaian Pendidikan yang harus dilakukan oleh seorang pendidik. Prosedur dan standar tersebut diantaranya: tahap persiapan penilaian, tahap pelaksanaan penilaian, tahap tindak lanjut penilaian, dan tahap pelaporan penilaian. Melihat kriteria prosedur dan standar penilaian di atas sudah seharusnya sebagai seorang pendidik melakukan dan menerapkan tahap-tahap penilaian belajar sesuai standar. Akan tetapi, pelaksanaan penilaian atau evaluasi di lapangan (di sekolah) khususnya penilaian belajar oleh guru produktif Teknik

\footnotetext{
${ }^{1}$ Mahasiswa Departemen Pendidikan Teknik Mesin FPTK UPI

2 Dosen Departemen Pendidikan Teknik Mesin FPTK UPI

3 Dosen Departemen Pendidikan Teknik Mesin FPTK UPI
} 
Kendaraan Ringan (TKR) terdapat beberapa permasalahan. Permasalahan tersebut tentunya harus kita pecahkan bersama-sama agar terciptanya pelaksanaan pendidikan yang berkualitas khususnya dalam pelaksanaan penilaian pendidikan ini. Oleh karena itu, perlu dikaji dan teliti mengenai kesesuaian antara pelaksanaan penilaian di SMK dengan standar penilaian yang telah diatur oleh pemerintah. Standar tersebut dijadikan sebagai bahan masukan atau rujukan bagi guru-guru produktif dilapangan dalam melaksanakan penilaian.

Evaluasi pendidikan merupakan kegiatan yang dapat membantu pemerintah dalam mencapai tujuannya (Daryanto, 2008). Hendaknya evaluator menggunakan berbagai teknik dan instrumen sehingga mampu mengungkap bentuk aspek. Dalam rangka mencapai tujuan penilaian pendidikan tersebut, pemerintah telah menyusun tujuan serta acuan pendidikan nasional mengenai penilaian. Acuan tersebut tertuang dalam Peraturan Menteri Pendidikan dan Kebudayaan Republik Indonesia Nomor 23 tahun 2016 dalam bentuk Standar Penilaian Pendidikan.

Standar Penilaian Pendidikan adalah kriteria mengenai lingkup, tujuan, manfaat, prinsip, mekanisme, dan prosedur. Instrumen penilaian hasil belajar peserta didik yang digunakan sebagai dasar dalam penilaian hasil belajar peserta didik pada pendidikan dasar dan pendidikan menengah. Penilaian adalah proses pengumpulan dan pengolahan informasi untuk mengukur pencapaian hasil belajar peserta didik (Colak and Kaya, 2014). Pembelajaran adalah proses interaksi antar peserta didik, antara peserta didik dengan pendidik dan sumber belajar pada suatu lingkungan belajar. Ulangan adalah proses yang dilakukan untuk mengukur pencapaian kompetensi peserta didik secara berkelanjutan dalam proses pembelajaran untuk memantau kemajuan dan perbaikan hasil belajar peserta didik. Ujian sekolah/madrasah adalah kegiatan yang dilakukan untuk mengukur pencapaian kompetensi peserta didik sebagai pengakuan prestasi belajar dan/atau penyelesaian dari suatu satuan pendidikan. Kriteria Ketuntasan Minimal (KKM) adalah kriteria ketuntasan belajar yang ditentukan oleh satuan pendidikan yang mengacu pada standar kompetensi kelulusan, dengan mempertimbangkan karakteristik peserta didik, karakteristik mata pelajaran, dan kondisi satuan pendidikan. Penilaian hasil belajar oleh pendidik dalam tahap persiapan memperhatikan hal-hal sebagai berikut: mengkaji kompetensi dan silabus sebagai acuan dalam membuat rancangan dan kriteria penilaian, mengembangkan indikator, memilih teknik penilaian sesuai dengan indikator, dan mengembangkan instrumen dan pedoman penskoran (Ismiyatun dan Hadi, 2013).

Penilaian hasil belajar oleh pendidik dalam tahap pelaksanaan memperhatikan halhal sebagai berikut: pelaksanaan penilaian dalam proses pembelajaran diawali dengan 
penelusuran. Penelusuran dilakukan dengan menggunakan teknik bertanya untuk mengeksplorasi pengalaman belajar sesuai dengan kondisi dan tingkat kemampuan peserta didik. Melaksanakan tes dan/atau nontes. Pelaksanaan penilaian pengetahuan dilakukan untuk menilai proses dan hasil belajar siswa. Penilaian tersebut dilakukan melalui penilaian harian $(\mathrm{PH} / \mathrm{UH})$, ujian tengah semester (UTS), dan ujian akhir semester (UAS). UTS merupakan kegiatan penilaian yang dilakukan untuk mengukur pencapaian kompetensi dasar mata pelajaran setelah kegiatan pembelajaran berlangsung 8-9 minggu. Cakupan penilaian harian meliputi satu kompetensi dasar atau lebih, sedangkan cakupan penugasan disesuaikan dengan karakteristik kompetensi dasar.

Penilaian hasil belajar oleh pendidik dalam tahap tindak lanjut memperhatikan halhal sebagai berikut: hasil penilaian oleh pendidik dianalisis lebih lanjut untuk mengetahui kemajuan dan kesulitan belajar. Hasil penilaian dikembalikan kepada peserta didik disertai balikan (feedback) berupa komentar yang mendidik (penguatan). Hasil analisis ditindaklanjuti dengan layanan remedial dan pengayaan, serta memanfaatkannya untuk perbaikan pembelajaran. Penilaian kompetensi sikap spiritual dan sosial antarmata pelajaran dilakukan oleh semua pendidik selama satu semester. Hasilnya diakumulasikan dan dinyatakan dalam bentuk deskripsi kompetensi sikap oleh wali kelas.

Pembelajaran remedial dapat dilakukan dengan cara: pemberian pembelajaran ulang dengan metode dan media yang berbeda, menyesuaikan dengan gaya belajar siswa. Pemberian bimbingan secara perorangan. Pemberian tugas-tugas atau latihan secara khusus, dimulai dengan tugas-tugas atau latihan sesuai dengan kemampuannya. Pemanfaatan tutor sebaya, yaitu siswa dibantu oleh teman sekelas yang telah mencapai ketuntasan belajar. Pembelajaran remedial dapat dilakukan sebelum semester berakhir atau batas akhir pemasukan nilai ke dalam buku rapor.

Penilaian hasil belajar oleh pendidik dalam tahap persiapan memperhatikan laporan hasil penilaian kompetensi pengetahuan dan keterampilan oleh pendidik berbentuk nilai dan deskripsi pencapaian kompetensi. Laporan hasil penilaian kompetensi sikap spiritual dan sosial dalam bentuk deskripsi sikap berdasarkan kumpulan informasi dari guru-guru mata pelajaran. Laporan hasil penilaian oleh pendidik disampaikan kepada kepala sekolah dan pihak lain yang terkait (misal: wali kelas, guru Bimbingan dan Konseling, dan orang tua/wali) pada periode yang ditentukan (Kamaruddin dan Haryanto, 2014). Rapor merupakan buku laporan kemajuan hasil belajar siswa berdasarkan hasil penilaian yang dilakukan oleh guru dalam kurun waktu tertentu. Hasil penilaian yang dilaporkan meliputi pencapaian kompetensi sikap (sikap spiritual dan sikap sosial), pengetahuan, dan 
keterampilan (Moldovan and Moldovan, 2016). Laporan kompetensi sikap diberikan dalam bentuk deskripsi, sedangkan pengetahuan dan keterampilan diberikan dalam bentuk bilangan bulat (skala 0-100), predikat dan dilengkapi dengan deskripsi.

\section{METODE PENELITIAN}

Metode yang digunakan adalah metode deskriptif. Penelitian deskriptif bermaksud untuk menyelidiki keadaaan, kondisi, situasi, peristiwa, keiatan, dan lain-lain, yang terkait denga penilaian pendidikan. Penelitian dilaksanakan di SMKN 6 Bandung. Populasi dalam penelitian ini yaitu siswa kelas X Teknik Kendaraan Ringan SMKN 6 Bandung tahun ajaran 2016/2017 yang berjumlah 210 siswa dari 6 kelas. Teknik pengambilan sampel dilakukan dengan simple random sampling, dimana pengambilan anggota sampel dari populasi dilakukan secara acak tanpa memperhatikan strata yang ada dalam populasi tersebut. Jumlah sampael sebanyak 68 orang. Instrumen penelitian digunakan observasi dan wawancaara.

\section{HASIL PENELITIAN}

Hasil penelitian telah diperoleh yang diringkas pada Tabel 1.

Tabel 1. Hasil Penelitian

\begin{tabular}{llcc}
\hline Tahap Penilaian & \multicolumn{1}{c}{ Indikator } & $\begin{array}{c}\text { Kesesuaian per } \\
\text { Indikator (\%) }\end{array}$ & $\begin{array}{c}\text { Kesesuaian per } \\
\text { Tahap (\%) }\end{array}$ \\
\hline 1.Persiapan & $\begin{array}{l}\text { a.Pengembangan indikator dari } \\
\text { Kompetensi Dasar }\end{array}$ & 100 & \\
& $\begin{array}{l}\text { b.Pemilihan teknik penilaian sesuai } \\
\text { dengan indicator }\end{array}$ & 93,3 & 87,1 \\
& $\begin{array}{l}\text { c.Pengembangan instrumen dan } \\
\text { pedoman penyekoran }\end{array}$ & 68 & \\
2.Pelaksanaan & $\begin{array}{l}\text { a.Penelusuran kemampuan awal siswa } \\
\text { b.Pelaksanaan tes dan/atau nontes }\end{array}$ & 55,8 & \\
& $\begin{array}{l}\text { c.Penggunaan teknik penilaian } \\
\text { 3.Tindak Lanjut }\end{array}$ & 65,1 & 77 \\
& $\begin{array}{l}\text { a.Paktu pelaksanaan ulangan } \\
\text { disertai feedback }\end{array}$ & 94,1 & \\
4.Pelaporan & $\begin{array}{l}\text { b.Pelaksanaan remedial } \\
\text { a.Pelaporan hasil penilaian } \\
\text { kompetensi pengetahuan dan } \\
\text { keterampilan (nilai dan deskripsi) }\end{array}$ & 24,2 & 43,2 \\
& b.Pelaporan hasil penilaian \\
kompetensi sikap (deskripsi) & 62,2 & \\
& & 66,7 & \\
& & 100 & 83,3 \\
\hline
\end{tabular}




\section{PEMBAHASAN}

Salah satu tugas profesional seorang guru yaitu harus mampu menguasai evaluasi/penilaian untuk menentukan hasil pembelajaran siswanya. Data kesesuaian hasil penelitian dalam hal pelaksanaan penilian diperoleh $87,1 \%$. Pelaksanaan persiapan penilaian belajar yang dilakukan oleh guru mata pelajaran sebagian besar telah sesuai dengan standar dan dapat dikategorikan dalam kondisi sangat baik. Evaluasi pendidikan merupakan kegiatan yang dapat membantu pemerintah dalam mencapai tujuannya. (Daryanto, 2008). Pelaksanaan persiapan penilaian belajar yang dilakukan oleh guru mata pelajaran dapat dikatakan sudah sangat relevan dan dapat membantu tujuan pemerintah dalam menciptakan pendidikan yang bermutu.

Standar penilaian yang diatur oleh pemerintah tentunya menginginkan pelaksanaan penilaian belajar yang dilakukan disekolah sesuai standar. Standar yang ditetapkan agar pendidikan di sekolah-sekolah memiliki kualitas yang bermutu (Direktorat Jenderal Pendidikan Dasar dan Menengah, 2015). Akan tetapi, data di atas menunjukkan bahwa tingkat kesesuaian antara tahap pelaksanaan penilaian belajar yang dilakukan oleh guru dengan standar yang ditetapkan belum sepenuhnya sesuai. Data kesesuaian yang dihasilkan yaitu mencapai $77 \%$. Pelaksanaan penilaian belajar yang dilakukan oleh guru mata pelajaran sebagian besar telah sesuai dengan standar dan dapat dikategorikan dalam kondisi baik.

Sebaiknya para evaluator menggunakan berbagai teknik dan instrumen sehingga mampu mengungkap bentuk aspek (Prasetya, 2012). Evaluator yang dimaksudkan disini yaitu seorang guru sebagai penilai dalam menentukan hasil pembelajaran bagi siswa. Teknik dan instrumen dalam pelaksanaan tes merupakan hal yang penting untuk dilakukan. Persentase kesesuaian sebesar $77 \%$ mengindikasikan bahwa pelaksanaan penilaian belajar (tes) yang dilakukan oleh guru mata pelajaran dapat dikatakan sudah mampu untuk mengungkap dan mendeskripsikan kompetensi siswa pada masing-masing aspek yakni pengetahuan, sikap dan keterampilan.

Data yang menunjukkan bahwa tingkat kesesuaian antara tahap tindak lanjut penilaian belajar yang dilakukan oleh guru dengan standar yang ditetapkan belum sepenuhnya sesuai. Data kesesuaian yang dihasilkan yaitu 43,2\%. Ditafsirkan pelaksanaan penilaian belajar yang dilakukan oleh guru mata pelajaran kurang dari setengahnya yang telah sesuai dengan standar dan dapat dikategorikan dalam kondisi kurang baik. Ini tentunya menjadi perhatian juga bagi pihak SMKN 6 Bandung agar lebih meningkatkan lagi kinerja dalam hal tindak lanjut penilaian ini. 
Salah satu fungsi penilaian yaitu berfungsi sebagai diagnostik. Diagnostik yang dimaksud yakni penilaian berfungsi untuk mengenal kelebihan dan kelemahan masingmasing siswa (Sarea dan Hadi, 2015). Tentunya fungsi diagnostik ini akan tercapai jika terpenuhinya tahap tindak lanjut dalam sebuah penilaian belajar. Hasil penelitian pada tahap tindak lanjut diperoleh persentase kesesuaian sebesar 43,2\%. Hal ini mengindikasikan bahwa tindak lanjut penilaian belajar yang dilakukan oleh guru mata pelajaran dapat dikatakan belum mampu untuk mendiagnosis/mengungkap kelemahan dan kelebihan dari kompetensi yang dimiliki siswa. Jika saja pada tahap tindak lanjut ini berjalan dengan baik, maka bukan tidak mungkin guru dan siswa akan menemukan kelebihan dan kekurangan pada masing-masing siswa untuk mendongkrak prestasi belajar yang dihasilkan.

Data menunjukkan bahwa tingkat kesesuaian antara tahap pelaporan penilaian belajar yang dilakukan oleh guru dengan standar yang ditetapkan belum sepenuhnya sesuai. Data kesesuaian diperoleh sebesar 83,3\%. Pelaporan penilaian belajar yang dilakukan oleh guru mata pelajaran sebagian besar yang telah sesuai dengan standar dan dapat dikategorikan dalam kondisi sangat baik.

Salah satu fungsi penilaian yaitu berfungsi sebagai pengukur keberhasilan (Arikunto, 2011). Besar kecilnya nilai yang diperoleh siswa berdasarkan kompetensinya masingmasing. Fungsi pengukur keberhasilan ini akan tercapai dan terdeskripsi dengan benar apabila dilaksanakannya standar-standar yang ada pada tahap pelaporan dalam sebuah penilaian belajar (Sukardi, 2011). Hasil penelitian pada tahap pelaporan ini diperoleh kesesuaian sebesar $83,3 \%$. Hal ini mengindikasikan bahwa pelaporan penilaian belajar yang dilakukan oleh guru mata pelajaran dapat dikatakan sudah mampu untuk mendeskripsikan ukuran keberhasilan hasil belajar siswanya dengan benar. Baik dalam aspek pengetahuan, sikap ataupun keterampilan.

\section{KESIMPULAN}

Kesimpulan dari hasil penelitian sebagai berikut: kesesuaian antara tahap persiapan penilaian belajar yang dilakukan oleh guru produktif telah sesuai dengan Standar Penilaian Pendidikan. Kesesuaian dengan standar tersebut dapat dikategorikan sangat baik. Kesesuaian antara tahap pelaksanaan penilaian belajar yang dilakukan oleh guru produktif dengan Standar Penilaian Pendidikan sebagian besar telah sesuai dengan standar dan dapat dikategorikan baik. Kesesuaian antara tahap tindak lanjut penilaian belajar yang dilakukan oleh guru produktif dengan Standar Penilaian Pendidikan kurang dari setengahnya yang telah sesuai dengan standar dan dapat dikategorikan kurang baik. Kesesuaian antara tahap 
pelaporan penilaian belajar yang dilakukan oleh guru produktif dengan Standar Penilaian Pendidikan sebagian besar telah sesuai dengan standar dan dapat dikategorikan sangat baik.

\section{REFERENSI}

Arifin, Z. (2012). Evaluasi Pembelajaran: Prinsip, Teknik, Prosedur. Bandung: PT. Remaja Rosdakarya.

Arikunto, S. (2011). Dasar-dasar Evaluasi Pendidikan. Jakarta: Bumi Aksara

Colak, E. \& Kaya, D. (2014). Learning Approaches of Vocational High School Students: Grade Level and School Type Influences. Journal of vocational and technical high schools, 116 (1), hlm. 1556-1561.

Daryanto, H. M. (2008). Evaluasi Pendidikan. Jakarta: Rineka Cipta.

Direktorat Jenderal Pendidikan Dasar dan Menengah. (2015). Panduan Penilaian pada Sekolah Menengah Kejuruan. Jakarta: Ditjen Dikdasmen.

Ismiyatun dan Hadi, S. (2013). Evaluasi Implementasi Standar Penilaian pada Pembelajaran Batik Sekolah Menengah Kejuruan di Daerah Istimewa Yogyakarta. Jurnal Evaluasi Pendidikan, 1 (2), hlm. 154-168.

Kamaruddin dan Haryanto. (2014). Pengembangan Sistem Penilaian Hasil Belajar Mata Pelajaran Menganalisis Rangkaian Listrik Berbasis Computerized Adaptive Testing. Jurnal Pendidikan Vokasi, 4 (1), hlm. 28-42.

Moldovan, L. \& Moldovan, A. M. (2016). Green Methodology for Learning Assessment. Journal of learning assessment, 22 (1), hlm. 1176-1183.

Prasetya, T. I. (2012). Meningkatkan Keterampilan Menyusun Instrumen Hasil Belajar Berbasis Modul Interaktif bagi Guru-Guru IPA SMPN Kota Magelang. Journal of Educational Research and Evaluation, 1 (2), hlm. 106-112.

Sarea, M. S. \& Hadi, S. (2015). Analisis Kualitas Soal Ujian Akhir Semester Mata Pelajaran Kimia SMA di Kabupaten Gowa. Jurnal Evaluasi Pendidikan, 3 (1), hlm. 35-43.

Sukardi. (2011). Evaluasi Pendidikan: Prinsip dan Operasionalnya. Jakarta: Bumi Aksara. 